NOTE

\title{
PCR detection of the crayfish plague pathogen in narrow-clawed crayfish inhabiting Lake Eğirdir in Turkey
}

\author{
J. Svoboda ${ }^{1}$, E. Kozubíková1 ${ }^{\text {, P. Kozák }}{ }^{2}$, A. Kouba ${ }^{2}$, S. Bahadir Koca ${ }^{3}$, Ö. Diler ${ }^{3}$, \\ I. Diler ${ }^{3}$, T. Policar ${ }^{2}$, A. Petrusek ${ }^{1, *}$ \\ ${ }^{1}$ Department of Ecology, Faculty of Science, Charles University in Prague, 12844 Prague 2, Czech Republic \\ ${ }^{2}$ Faculty of Fisheries and Protection of Waters, South Bohemian Research Center of Aquaculture and Biodiversity of \\ Hydrocenoses and Research Institute of Fish Culture and Hydrobiology, University of South Bohemia in České Budějovice, \\ 38925 Vodňany, Czech Republic \\ ${ }^{3}$ Eğirdir Fisheries Faculty, Süleyman Demirel University, 32500 Eğirdir, Isparta, Turkey
}

\begin{abstract}
Many populations of the narrow-clawed crayfish Astacus leptodactylus in Turkey, including those inhabiting Lake Eğirdir, declined drastically in the mid-1980s due to introduction of crayfish plague Aphanomyces astaci. However, unlike many other localities, there has been some recovery in the A. leptodactylus population inhabiting this lake even though crayfish plague has been suspected to have persisted since then. In support of this, DNA from 5 of 34 healthy-looking crayfish sampled recently from the lake tested positive by both conventional and real-time PCR using species-specific primers targeting the rDNA internal transcribed spacer region, and product sequence analysis confirmed the identification of $A$. astaci. This complies with other recent reports of coexistence of native European crayfish with this pathogen, and further research is now needed to identify the key mechanisms allowing it.
\end{abstract}

KEY WORDS: Aphanomyces astaci - Astacus leptodactylus - Host-pathogen coexistence · Melanisation $\cdot$ rDNA-internal transcribed spacer sequence $\cdot$ Lake Eğirdir

\section{INTRODUCTION}

Beginning in the $1860 \mathrm{~s}$, the Aphanomyces astaci oomycete that causes crayfish plague has spread across Europe decimating native crayfish species (Alderman 1996). Although the disease has the potential to completely annihilate populations of native European crayfish (Reynolds 1988, Alderman 1993, Diéguez-Uribeondo 2006, Kozubíková et al. 2008), in some lakes in Finland (Jussila et al. 2011b, Viljamaa-Dirks et al. 2011) and elsewhere (Sweden: Fürst 1995; Turkey: Harlioğlu 2004, 2008) such crayfish seem to coexist with the pathogen. Specific local water chemistries, low host population densities, variations in strain virulence and variable crayfish resistance have been suggested as potential reasons for this.

Narrow-clawed crayfish Astacus leptodactylus (Eschscholtz, 1823) are native to Eastern Europe and adjacent regions and have been harvested commercially in Turkey since the 1960s (Rahe \& Soylu 1989). In 1985 and 1986, crayfish catch numbers collapsed catastrophically due to crayfish plague (Fürst \& Söderhäll 1987, Baran \& Soylu 1989, Rahe \& Soylu 1989, Timur 1990). Almost all populations affected by this disease either disappeared completely or were 
dramatically reduced. However, there were exceptional cases where crayfish numbers either remained continuously high or recovered enough to sustain commercial harvesting despite the presumed presence of the crayfish plague pathogen (Rahe \& Soylu 1989, Harlioğlu 2004, 2008).

Crayfish resistance and/or unique water chemistries have been assumed as reasons facilitating the long-term coexistence of Aphanomyces astaci in crayfish inhabiting such lakes (Rahe \& Soylu 1989, Harlioğlu 2008). A. astaci was unambiguously proven as the cause of crayfish mortalities in the 1980s (Baran \& Soylu 1989, Rahe \& Soylu 1989, Huang et al. 1994). However, its later presence in Turkish lakes (e.g. Aydin \& Dilek 2004, Harlioğlu 2004, 2008) has only been assumed from symptoms that are not specific for the crayfish plague pathogen (Cerenius et al. 1988, Oidtmann et al. 1999). As A. astaci should not survive at a locality when its crayfish hosts disappear (Söderhäll \& Cerenius 1999) and its presence in Turkey after 1989 has not been proven definitively, its distribution in the country might now be more restricted than assumed.

The narrow-clawed crayfish population inhabiting Lake Eğirdir (Isparta Province; $38^{\circ} \mathrm{N}, 31^{\circ} \mathrm{E}$, altitude $917 \mathrm{~m}$ above sea level [a.s.l.], area $482 \mathrm{~km}^{2}$ ) collapsed in 1986, presumably due to crayfish plague (Fürst \& Söderhäll 1987). By 1999, numbers recovered sufficiently to allow commercial harvesting, although catch sizes have been lower and prone to fluctuations (Fig. 1). The aim of this study was to examine Lake Eğirdir crayfish using PCR and rDNA sequence analysis to test for the contemporary presence of $A$. astaci.

\section{MATERIALS AND METHODS}

Over 2 occasions in 2009, a total of 32 crayfish (mean body length \pm SD: $111 \pm 22 \mathrm{~mm}$ ) were caught in fyke-net traps in the southern part of Lake Eğirdir $\left(37^{\circ} 53^{\prime} \mathrm{N}, 30^{\circ} 53^{\prime} \mathrm{E}\right)$. In March, 2 egg-bearing females were caught and kept in a tank until June, when samples of their tissues and 1 juvenile from each of their broods were collected for analysis. In November, 30 more crayfish were captured and their tissues sampled shortly after capture. Both crayfish captured in March as well as their offspring and 13 of the 30 crayfish captured in November displayed melanised spots of various sizes (1 to $10 \mathrm{~mm}$ diam.), which might develop in response to Aphanomyces astaci hyphae (Unestam 1969, Fürst \& Söderhäll 1987, Baran \& Soylu 1989) but also to other pathogens (Söderhäll \& Cerenius 1998). One uropod, soft abdominal cuticle, eye stalk, walking leg joint, and prominent melanised cuticle regions of each crayfish were dissected aseptically and preserved in $96 \%$ ethanol. Up to $50 \mathrm{mg}$ of this material crushed in

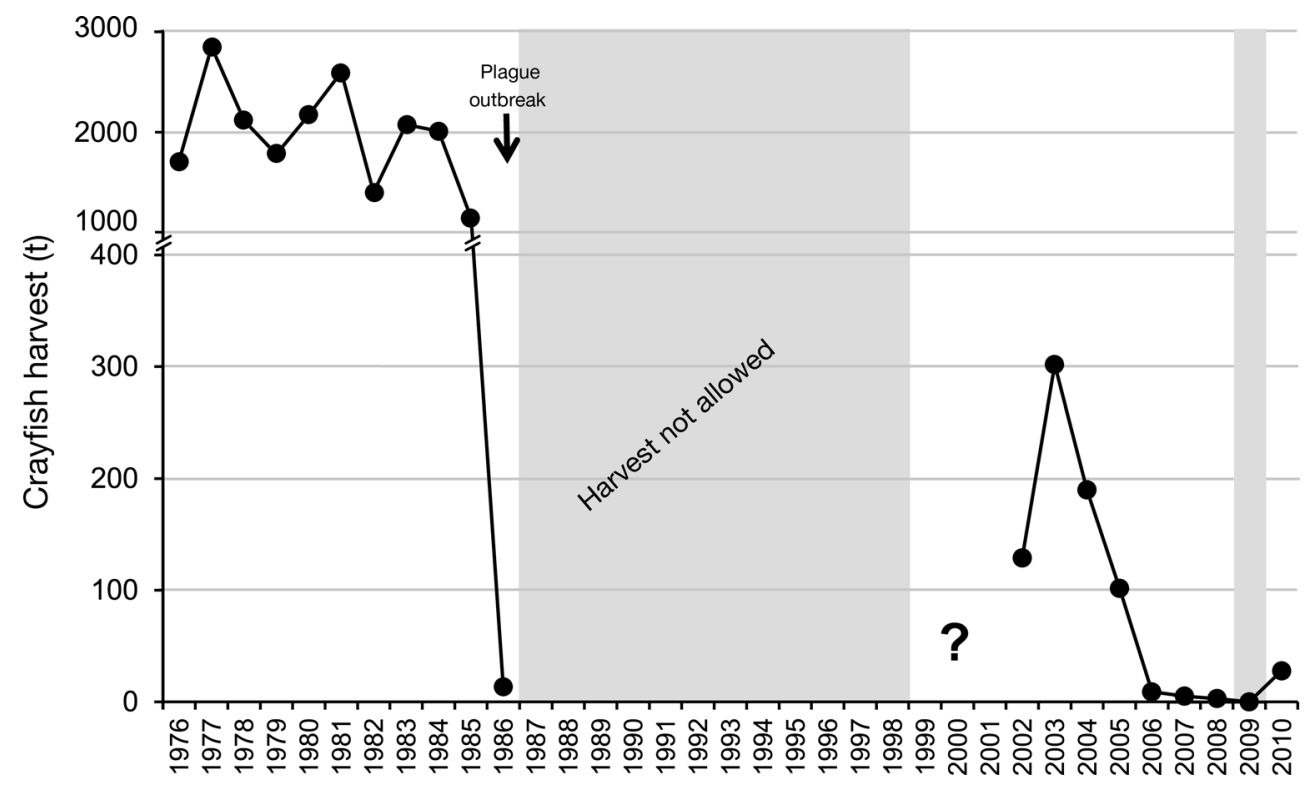

Fig. 1. Astacus leptodactylus. Annual crayfish harvest from Lake Eğirdir between 1976 and 2010. Periods when capture of crayfish was banned are shaded, and the 1986 crayfish plague outbreak is indicated. Data from 1976 to 1986 (Gülle et al. 2008) and from 2002 to 2010 (Eğirdir Town Food, Agriculture and Livestock Directorate) reflect official catches reported by local fishermen. No reliable harvest data were found between 1999 and 2001 


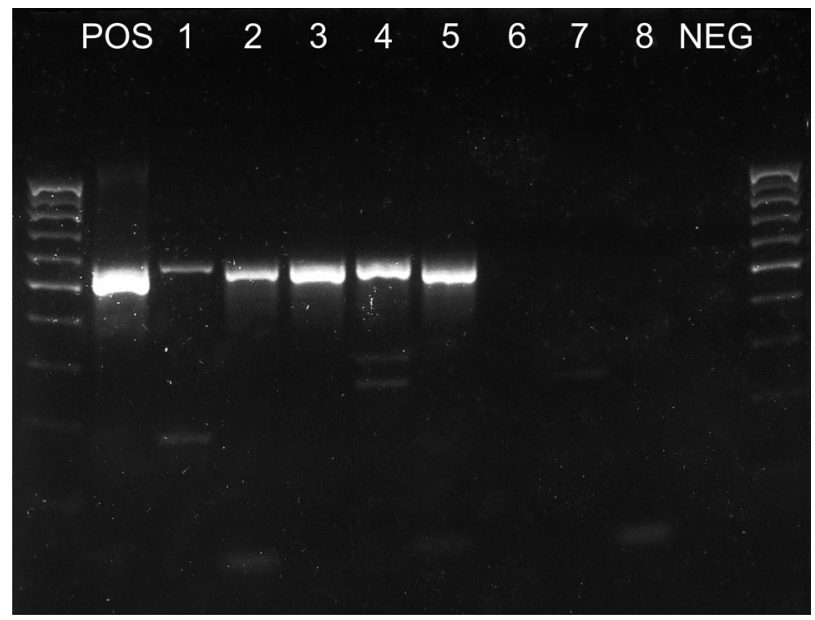

Fig. 2. Astacus leptodactylus. Agarose gel showing the $\sim 550$ bp rDNA internal transcribed spacer (ITS) region PCR product amplified using primers specific for Aphanomyces astaci and 10x diluted DNA from 8 selected narrow-clawed crayfish captured from Lake Eğirdir in 2009. Each lane corresponds to product from an individual crayfish. POS: DNA isolated from pure laboratory culture of $A$. astaci. NEG: no template control; $100 \mathrm{bp}$ size markers were loaded to side lanes

liquid nitrogen was used to extract DNA using a DNeasy tissue kit (QIAGEN).

Undiluted DNA and DNA diluted $10 \times$ to overcome potential effects of PCR inhibitors (Vrålstad et al. 2009) were amplified using a PCR protocol targeting an internal transcribed spacer (ITS) region of the Aphanomyces astaci rDNA gene (Oidtmann et al. 2006). DNA isolated from a laboratory culture of this pathogen was used as a PCR positive control, and PCR products visualized by agarose gel electrophoresis were sequenced and compared to published A. astaci sequences. To validate putative detections, DNA isolates were also analysed using an A. astaci-specific TaqMan real-time PCR protocol (Vrålstad et al. 2009).

\section{RESULTS}

PCR products corresponding in size to that amplified from Aphanomyces astaci DNA were obtained from both females and 1 juvenile sampled in June and from 2 of the 30 crayfish captured in November (Fig. 2). DNA from these individuals also tested positive by real-time PCR. For 1 of the 2 crayfish captured in November, a PCR product was only amplified from $10 \times$ diluted DNA, suggesting the presence of inhibitors. All 5 PCR-positive crayfish came from the
17 exhibiting some degree of cuticle melanisation. Sequences determined for the 5 PCR products were identical (GenBank JN185321) and corresponded exactly to ITS-rDNA sequences published for all genetic groups of A. astaci known presently (Huang et al. 1994, Diéguez-Uribeondo et al. 1995, 2009, Kozubíková et al. 2011).

\section{DISCUSSION}

These data confirm unambiguously the existence of an Aphanomyces sp. with an ITS sequence corresponding exactly to the crayfish plague pathogen in some narrow-clawed crayfish inhabiting Lake Eğirdir in 2009, and we thus consider it a proof of contemporary presence of $A$. astaci in Turkey. However, as no PCR detections of $A$. astaci were made in 12 of 17 crayfish exhibiting cuticle melanisation, this does not seem to be a specific indicator of crayfish plague; such symptoms in Turkish crayfish should be interpreted with care (see Fürst \& Söderhäll 1987, Rahe \& Soylu 1989, Diler \& Bolat 2001).

Aphanomyces astaci was detected in 2 Astacus leptodactylus crayfish that survived rearing in captivity for 3 mo. This finding supports recent reports of latent infections occurring in noble crayfish A. astacus (L. 1758) populations in Finland (Jussila et al. 2011b, Viljamaa-Dirks et al. 2011) and detections of A. astaci in apparently healthy A. leptodactylus inhabiting the Danube Delta in Romania (Pârvulescu et al. 2012). Considering the history of crayfish harvest in the lake and the time separating our study and previous unambiguous diagnoses of the pathogen in Turkey, we conclude that $A$. astaci may have indeed persisted in the lake for over 2 decades without eliminating the local crayfish population.

Several hypotheses may explain the continuing coexistence of crayfish plague in narrow-clawed crayfish inhabiting previously affected lakes in Turkey, although none are supported fully by available data. In lakes such as İznik and Akşehir where crayfish populations persisted, unique water chemistry has been suggested to have played some role (Fürst \& Söderhäll 1987, Rahe \& Soylu 1989, Harlioğlu 2004, 2008). However, the Astacus leptodactylus population disappeared completely from Lake Akşehir after 1990, apparently due to crayfish plague (Harlioğlu 2008), despite the presumed protective effect of elevated concentrations of magnesium ions (127 $\mathrm{mg} \mathrm{Mg}^{2+} \mathrm{l}^{-1}$; Rahe \& Soylu 1989). As magnesium ion concentrations are substantially lower in Lake Eğirdir (5 to $59 \mathrm{mg} \mathrm{Mg}^{2+} \mathrm{l}^{-1}$; Gülle et al. 
2008), it does not seem to be the main factor responsible for sparing crayfish from acute disease and death.

More likely, the long-term coexistence with the crayfish plague pathogen may be due to increased resistance of local crayfish to the disease. However, whilst evidence of Astacus leptodactylus resistance has been found in some challenge experiments (Unestam 1969, Fürst \& Söderhäll 1987, Fürst 1995), no evidence of resistance has been found in others (Alderman et al. 1987, Baran \& Soylu 1989, Rahe \& Soylu 1989). Whether these conflicting observations have been caused by variations in the susceptibility of crayfish stocks sourced from different locations, as found recently with noble crayfish (Jussila et al. 2011a), or variable exposure to other stress factors impairing crayfish defence responses has yet to be resolved. The long-term coexistence of noble crayfish with the crayfish plague pathogen across Fennoscandia has also been attributed to possibly reduced virulence of some Aphanomyces astaci strains as well as to inefficient pathogen dispersal in low-density populations of crayfish (Fürst 1995, Viljamaa-Dirks et al. 2011). Although differences in virulence among $A$. astaci strains are directly or indirectly supported by experimental data (Diéguez-Uribeondo et al. 1995, Viljamaa-Dirks \& Torssonen 2008), the simultaneous impact of crayfish plague across Turkish lakes in the 1980s suggests that a highly virulent strain was introduced. Nevertheless, subsequent local adaptation of crayfish and/or the parasite cannot be excluded in the lakes in which crayfish populations avoided complete decimation.

While low population densities may limit pathogen spread and impact, available data on Astacus leptodactylus densities in Lake Eğirdir are scarce and limited to short time periods in different parts of the lake. However, crayfish densities estimated in 2 such local studies decreased from 1.9-5.1 to 0.5-1.2 ind. $\mathrm{m}^{-2}$ between 1999-2000 and 2005 (Bolat 2004, Bolat et al. 2011), which corresponds to decreases in harvests over the same period (Fig. 1). Harvests since 1999 have generally been 1 to 2 orders of magnitude lower than those in the early 1980s before crayfish plague appeared and dropped again steeply after 2004 prompting the introduction of a harvest ban in 2009. Crayfish plague seems to have persisted in lower-density crayfish populations in Turkish lakes decimated by disease in the mid-1980s (Fürst \& Söderhäll 1987). The long-term data from Lake Eğirdir suggest that the presence of the pathogen may have prevented recovery of the populations to pre-exposure numbers and sporadically impacts remaining crayfish. However, while these observations suggest some A. leptodactylus crayfish might have adapted to better resist the pathogen and its impact might be limited by low host densities, future larger-scale studies will be needed to evaluate these hypotheses.

Although the mechanisms allowing the long-term coexistence of Aphanomyces astaci with crayfish in Turkey remain to be identified, the data presented here support other recent evidence of crayfish in Europe coexisting with this parasite over extended periods of time in chronic rather than acute infection states (Jussila et al. 2011b, Viljamaa-Dirks et al. 2011, Pârvulescu et al. 2012). As crayfish plague remains a major threat to indigenous Old World crayfish species both in the wild and in aquaculture (Souty-Grosset et al. 2006), further studies are needed to better understand its virulence, host interactions and epidemiology to devise strategies for recovery of native crayfish populations.

Acknowledgements. This study was supported by the Czech Ministry of Education (CZ.1.05/2.1.00/01.0024 and ME 10125), the Grant Agency of the University of South Bohemia (047/2010/Z) and the Czech Science Foundation (206/08/H049). We thank T. Fér, V. Kučabová, L. Flašková and E. Dušková (Department of Botany, Charles University, Prague) for support in the DNA lab, and J. Cowley for streamlining the manuscript text.

\section{LITERATURE CITED}

Alderman DJ (1993) Crayfish plague in Britain, the first twelve years. Freshw Crayfish 9:266-272

Alderman DJ (1996) Geographical spread of bacterial and fungal diseases of crustaceans. Rev Sci Tech Off Int Epiz 15:603-632

Alderman DJ, Polglase JL, Frayling M (1987) Aphanomyces astaci pathogenicity under laboratory and field conditions. J Fish Dis 10:385-393

Aydin H, Dilek MK (2004) Effects of different water temperatures on the hatching time and survival rates of the freshwater crayfish Astacus leptodactylus (Esch., 1823) eggs. Turk J Fish Aquat Sci 4:75-79

Baran I, Soylu E (1989) Crayfish plague in Turkey. J Fish Dis 12:193-197

Bolat Y (2004) Estimation of density and catchable stock of the crayfish (Astacus leptodactylus Esch. 1823) by markrecapture method in Hoyran district of Eğirdir Lake, Turkey. Süleyman Demirel Üniversitesi Fen Bilimleri Enstitüsü Dergisi 8:34-37 (in Turkish with English abstract)

Bolat Y, Mazlum Y, Demirci A, Uğur Koca H (2011) Estimating the population size of Astacus leptodactylus (Decapoda: Astacidae) by mark-recapture technique in Eğirdir lake, Turkey. Afr J Biotechnol 10:11778-11783 
Cerenius L, Söderhäll K, Persson M, Ajaxon R (1988) The crayfish plague fungus Aphanomyces astaci-diagnosis, isolation, and pathobiology. Freshw Crayfish 7:131-144

Diéguez-Uribeondo J (2006) The dispersion of the Aphanomyces astaci-carrier Pacifastacus leniusculus by humans represents the main cause of disappearance of the indigenous crayfish Austropotamobius pallipes in Navarra. Bull Fr Peche Piscicult 380-381:1303-1312

Diéguez-Uribeondo J, Huang TS, Cerenius L, Söderhäll K (1995) Physiological adaptation of an Aphanomyces astaci strain isolated from the freshwater crayfish Procambarus clarkii. Mycol Res 99:574-578

Diéguez-Uribeondo J, García MA, Cerenius L, Kozubíková E and others (2009) Phylogenetic relationships among plant and animal parasites, and saprotrophs in Aphanomyces (Oomycetes). Fungal Genet Biol 46:365-376

Diler Ö, Bolat Y (2001) Isolation of Acremonium species from crayfish, Astacus leptodactylus in Eğirdir Lake. Bull Eur Assoc Fish Pathol 21:164-168

Fürst M (1995) On the recovery of Astacus astacus L. populations after an epizootic of the crayfish plague (Aphanomyces astaci Shikora). Freshw Crayfish 8:565-576

Fürst M, Söderhäll K (1987) The crayfish Astacus leptodactylus in Turkey: diseases and present distribution of the crayfish plague Aphanomyces astaci. FAO Report, Rome

Gülle I, Zeki Yildirm M, Küçük F (2008) Limnological history of Lake Eğirdir (Turkey): from 1950's to the present. Natura Montenegrina 7:115-128

Harlioğlu MM (2004) The present situation of freshwater crayfish, Astacus leptodactylus (Eschscholtz, 1823) in Turkey. Aquaculture 230:181-187

Harlioğlu MM (2008) The harvest of the freshwater crayfish Astacus leptodactylus Eschscholtz in Turkey: harvest history, impact of crayfish plague, and present distribution of harvested populations. Aquacult Int 16:351-360

Huang TS, Cerenius L, Söderhäll K (1994) Analysis of genetic diversity in the crayfish plague fungus, Aphanomyces astaci, by random amplification of polymorphic DNA. Aquaculture 126:1-9

> Jussila J, Makkonen J, Kokko H (2011a) Peracetic acid (PAA) treatment is an effective disinfectant against crayfish plague (Aphanomyces astaci) spores in aquaculture. Aquaculture 320:37-42

> Jussila J, Makkonen J, Vainikka A, Kortet R, Kokko H (2011b) Latent crayfish plague (Aphanomyces astaci) infection in a robust wild noble crayfish (Astacus astacus) population. Aquaculture 321:17-20

Kozubíková E, Petrusek A, Duriš Z, Martín MP, DiéguezUribeondo J, Oidtmann B (2008) The old menace is back: recent crayfish plague outbreaks in the Czech Republic.

Editorial responsibility: Jeff Cowley, Brisbane, Queensland, Australia
Aquaculture 274:208-217

Kozubíková E, Viljamaa-Dirks S, Heinikainen S, Petrusek A (2011) Spiny-cheek crayfish Orconectes limosus carry a novel genotype of the crayfish plague pathogen Aphanomyces astaci. J Invertebr Pathol 108:214-216

Oidtmann B, Schmid I, Rogers D, Hoffmann RW (1999) An improved isolation method for the cultivation of the crayfish plague fungus, Aphanomyces astaci. Freshw Crayfish 12:303-312

Oidtmann B, Geiger S, Steinbauer P, Culas A, Hoffmann RW (2006) Detection of Aphanomyces astaci in North American crayfish by polymerase chain reaction. Dis Aquat Org 72:53-64

Pârvulescu L, Schrimpf A, Kozubíková E, Cabanillas Resino S, Vrålstad T, Petrusek A, Schulz R (2012) Invasive crayfish and crayfish plague on the move: first detection of the plague agent Aphanomyces astaci in the Romanian Danube. Dis Aquat Org 98:85-94

Rahe R, Soylu E (1989) Identification of the pathogenic fungus causing destruction to Turkish crayfish stocks (Astacus leptodactylus). J Invertebr Pathol 54:10-15

> Reynolds JD (1988) Crayfish extinctions and crayfish plague in central Ireland. Biol Conserv 45:279-285

Söderhäll K, Cerenius L (1998) Role of the prophenoloxidase-activating system in invertebrate immunity. Curr Opin Immunol 10:23-28

Söderhäll K, Cerenius L (1999) The crayfish plague fungus: history and recent advances. Freshw Crayfish 12:11-36

Souty-Grosset C, Holdich DM, Noël PY, Reynolds JD, Haffner P (2006) Atlas of crayfish in Europe. Muséum National d'Histoire Naturelle, Paris

Timur G (1990) Crayfish plague in some lakes of Turkey. Bull Eur Assoc Fish Pathol 10:100-103

Unestam T (1969) Resistance to the crayfish plague in some American, Japanese and European crayfishes. Rep Inst Freshw Res Drottningholm 49:202-209

Viljamaa-Dirks S, Torssonen H (2008) Crayfish disease research at the Kuopio Unit, Finnish Food Safety Authority Evira. In: Viljamaa-Dirks S (ed) Crayfish disease diagnostics - towards a Nordic standard. Finnish Food Safety Authority Evira Research Department, Kuopio, p 30

Viljamaa-Dirks S, Heinikainen S, Nieminen M, Vennerström P, Pelkonen S (2011) Persistent infection by crayfish plague Aphanomyces astaci in a noble crayfish population-a case report. Bull Eur Assoc Fish Pathol 31: $182-188$

Vrålstad T, Knutsen AK, Tengs T, Holst-Jensen A (2009) A quantitative TaqMan MGB real-time polymerase chain reaction based assay for detection of the causative agent of crayfish plague Aphanomyces astaci. Vet Microbiol 137:146-155

Submitted: May 11, 2011; Accepted: January 17, 2012 Proofs received from author(s): March 20, 2012 